ПОГРІБНІЧЕНКО І.М.

\title{
РІЗНОВИДИ ІНДИВІДУАЛЬНИХ АКТІВ, ЩО МОЖУТЬ БУТИ ОСКАРЖЕНІ В АДМІНІСТРАТИВНОМУ СУДІ
}

У статті здійснено спробу визначити перелік індивідуальних актів, що можуть бути оскаржені в адміністративному суді. Мета статті - з'ясувати, які різновиди індивідуальних актів можуть бути оскаржені в адміністративному суді, а які - ні. Зазначена тематика $є$ настільки обширною, що до неї звертали свої наукові пошуки майже всі адміністративісти сучасності. Однак у зазначеному руслі дослідження не здійснювалися, тож сформувати типовий перелік індивідуальних актів, які можуть бути оскаржені в адміністративному суді, складно. Кожна справа є індивідуальною. Приблизний перелік, на переконання автора, виглядає так: 1) постанови по справі про адміністративне правопорушення; 2) рішення державних виконавців; 3) накази про затвердження узагальнюючої податкової консультації або письмово оформлена податкова консультація; 4) письмові вимоги будь-якого контролюючого органу; 5) рішення про реєстрацію (наприклад, податкової накладної / розрахунку коригування в Єдиному реєстрі податкових накладних та / або відмову в такій реєстрації та рішення про включення в ризикові); 6) накази щодо питань проходження публічної служби (як приклад Головного управління Національної поліції); 7) інші індивідуалізовані, конкретизовані рішення органів виконавчої влади наприклад, постанови Департаменту Державної архітектурно-будівельної інспекції, постанови Національної комісії, що здійснює державне регулювання у сферах енергетики та комунальних послуг. Наголошено, що не всі акти можна оскаржити. Зокрема, підставою для відмови в оскарженні є припинення дії такого акта (його виконання), а також відсутність порушення безпосередньо прав, свобод чи охоронюваних законом інтересів позивача (i не належний позивач, і не відсутність порушення як такого). Зроблено висновок, що інститут оскарження індивідуальних актів суб'єктів владних повноважень вважається одним із фундаментальних у системі адміністративного судочинства. Суб'єкти, наділені владними функціями, не завжди дотримуються встановлених правил прийняття (створення) актів застосування, що нерідко призводить до порушення прав об'єктів управління (якими ті є).

Ключові слова: адміністративний акт, акт, індивідуальний акт, нормативно-правовий акт, оскарження.

The author attempts to determine the list of individual acts that can be appealed in administrative court. The article directly presented aims to find out which types of individual acts may be appealed in administrative court and which are not.The author noted that these topics are so extensive that almost all administrative administrators of the present day have turned their scientific research to the problems, whether in a joint or in some aspects. However, their scientific studies were not carried out in the direction indicated by them. The study revealed that it is quite difficult to formulate a standard list of individual acts that can be appealed to an administrative court. Each case is individual. However, a more or less approximate list, in the opinion of the author, looks like this: 1) rulings on a case of an administrative offense; 2) decisions of state executors; 3 ) orders for approval of general tax advice or written tax advice; 4) written requirements of any controlling authority; 5) the decision on registration (for example, tax invoice / calculation of adjustment in the Unified Register of tax invoices and / or refusal of such registration and the decision on inclusion in risk); 6) orders for public service issues (as an example of the National Police Directorate General); 7) other individualized, specific decisions of executive authorities, for example, the resolution of the State Architectural

(C) ПОГРІБНІЧЕНКО І.М. - здобувач (Науково-дослідний інститут публічного права) 
and Construction Inspection Department, the resolution of the National Commission for State Regulation in the Energy and Communal Spheres services.It is emphasized that not all acts can be challenged. In particular, the ground for refusing an appeal is the termination of such an act (its execution), as well as the absence of a violation of the rights, freedoms or lawfully protected interests of the plaintiff (and not a proper plaintiff, nor the absence of a violation as such). It is concluded that the institution of appeal of individual acts of the subjects of power is considered as one of the fundamental in the system of administrative justice. Entities endowed with power do not always adhere to established rules for the adoption (creation) of acts of application, which often leads to a violation of the rights of management objects (as they are in this case).

Key words: act, administrative act, appeal, individual act, regulatory act.

Вступ. Захист прав людини і громадянина - це глобальне завдання сучасної правової, демократичної держави, яке вирішується й у планетарному, і національних масштабах. Кожна держава, виходячи із принципів і норм Загальної декларації прав людини, створює механізм захисту прав людини і громадянина, встановлює нормативні вимоги до ії здійснення. У Конституції України закріплено не тільки примат прав людини і громадянина, а й те, що їх захист гарантується, а така гарантія покладається переважно на державу та ії̈ органи. 3 цією метою в нашій державі створено судову систему, в діяльності якої значне місце відведено адміністративному суду [1, с. 23].

У ст. 19 Кодексу адміністративного судочинства України визначено перелік справ, на які поширюється юрисдикція адміністративних судів. Частина перша зазначеної статті передбачає, що до справ у публічно-правових спорах належать спори фізичних чи юридичних осіб із суб'єктом владних повноважень щодо оскарження його рішень (нормативно-правових актів чи індивідуальних актів) [2].

Наша стаття має на меті з'ясувати, які різновиди індивідуальних актів можуть бути оскаржені в адміністративному суді, а які - ні.

Зазначена тематика є настільки широкою, що до неї звертали свої наукові пошуки майже всі адміністративісти сучасності. Однак у зазначеному руслі наукові дослідження не здійснювалися.

Результати дослідження. Уточнюючи, зазначимо, що судовий порядок оскарження рішень органів публічної влади, їхніх посадових осіб передбачає можливість звернення особи, права якої порушені або можуть бути порушені, до суду відповідної юрисдикції з позовом (зверненням, скаргою, заявою), в якому викладаються аргументи щодо неправомірності прийняття рішення та вимоги щодо його зміни, скасування тощо та зобов'язання суду розглянути такий позов і прийняти аргументоване рішення. Сьогодні громадянам України доступні три інститути судового захисту, що мають повноваження встановлювати правомірність чи протиправність прийнятих рішень органами публічної влади, їхніми посадовими особами, це - адміністративна юстиція, Конституційний Суд і Європейський суд з прав людини [3, с. 75].

Як свідчить аналіз судової практики та розгляду адміністративних справ, реалізовуючи своє право на звернення до адміністративного суду, особи висловлюють вимогу про: 1) скасування акта індивідуальної дії; 2) оскарження правового акта індивідуальної дії (визнання правового акта індивідуальної дії незаконним); 3) визнання недійсним правового акта індивідуальної дії; 4) визнання протиправними та скасування актів індивідуальної дії; 5) оскарження акта індивідуальної дії; 6) про визнання протиправним і скасування рішення.

Верховний Суд України у справі № 09/236 зазначив, що, вирішуючи спір щодо встановлення незаконності акта суб'єкта владних повноважень, слід з'ясувати юридичну природу цього акта управління, визначитися щодо належності його до нормативно-правових актів чи до правових актів індивідуальної дії та навести у своєму рішенні відповідні доводи. 3'ясування цієї обставини має істотне значення для правильного вирішення справи, оскільки нормативно-правові акти можуть бути оскаржені широким колом осіб (фізичних і юридичних), яких вони стосуються. Індивідуальні ж акти можуть бути оскаржені лише особами, безпосередні права, свободи чи охоронювані законом інтереси яких такими актами порушені [4]. Слід зауважити, що певний акт, виданий суб'єктом владних повноважень, не може мати одночасно і характер нормативно-правового акта, й акта індивідуальної дії [5].

Правовий акт індивідуальної дії, виданий суб'єктом владних повноважень, - це документ, який прийнятий із метою реалізації положень нормативно-правового акта (актів) щодо конкретної життєвої ситуації, не містить загальнообов'язкових правил поведінки та стосується прав і обов'язків чітко визначеного суб'єкта (суб'єктів), котрому він адресований [6]. 
Загальною рисою, яка відрізняє індивідуальні акти управління, є їхній виражений правозастосовний характер. Головною рисою таких актів $є$ конкретність, а саме: чітке формулювання конкретних юридичних волевиявлень суб'єктами адміністративного права, що видають такі акти; розв'язання за їх допомогою конкретних, а саме індивідуальних справ або питань, які виникають у сфері державного управління; чітка визначеність адресата конкретної особи або осіб; виникнення конкретних адміністративно-правових відносин, зумовлених цими актами [4].

Тобто враховуючи, що за владно-регулятивною природою всі юридичні акти поділяються на правотворчі, правотлумачні (правоінтерпретаційні) та правозастосовні, нормативно-правові акти належать до правотворчих, а індивідуальні - до правозастосовних [7].

Уточнимо, що акт застосування права, з одного боку, виступає засобом організації реалізації правових норм, а з іншого - засобом здійснення процесу управління (у чому полягає його головна соціальна цінність). У ході правозастосовної діяльності органи правозастосування виступають суб'єктами управління; особи, щодо котрих застосовується право, - об'єктами управління; а правозастосовні акти - засобами управління [8, с. 34].

Часто адміністративні акти плутають 3 іншими документами, які видаються суб'єктами владних повноважень. Це можуть бути юридично нейтральні дії, такі як інформування (наприклад, інформування фізичної чи юридичної особи суб'єктом владних повноважень про прийняте рішення), листування, роз'яснення, або ж їх плутають із документами, що підтверджують певні стани, факти або права власності. У судовій практиці $є$ випадки, коли зацікавлена особа оскаржує свідоцтво про право власності або ліцензію, вважаючи, що цим свідоцтвом чи ліцензією порушено її права, домагається скасування документа, який $є$ лише підтвердженням того, що у певної особи є певне право [9].

Відповідно, до правових актів індивідуальної дії належать рішення суб'єкта владних повноважень, які поширюються на конкретних фізичних чи юридичних осіб і $є$ актом одноразового застосування норм права. Такими актами можуть бути рішення щодо проходження публічної служби (прийняття на роботу, притягнення до дисциплінарної відповідальності, звільнення з посади), призначення пенсії, рішення податкових органів тощо, а також рішення органів місцевого самоврядування, органів виконавчої влади, їхньої посадової чи службової особи, якими порушуються права, свободи та інтереси фізичних і юридичних осіб у сфері публічно-правових відносин $[10$, c. 284$]$.

Під час розгляду таких спорів судам необхідно враховувати, що до правових актів індивідуальної дії належать також рішення (постанови) про притягнення фізичних осіб до адміністративної відповідальності, які прийняті суб'єктами владних повноважень (крім суду) [11], оскільки мають конкретний припис, звернений до індивіда, зокрема: на підставі встановленого правопорушення та відповідно до правопорушення особа притягується до адміністративної відповідальності, на неї накладається адміністративне стягнення [12], а також рішення державних виконавців чи / або інших посадових осіб органів державної виконавчої служби під час здійснення ними виконавчого провадження [11].

Загалом сформувати типовий перелік індивідуальних актів, які можуть бути оскаржені до адміністративного суду, складно. Кожна справа $є$ індивідуальною. Однак приблизний перелік, на наш погляд, такий:

1) постанови по справі про адміністративне правопорушення;

2) рішення державних виконавців;

3) накази про затвердження узагальнюючої податкової консультації або письмово оформлена податкова консультація;

4) письмові вимоги будь-якого контролюючого органу, оскільки такий акт породжує правові наслідки (зокрема обов'язки) для свого адресата і наділений рисами правового акта індивідуальної дії (з урахуванням його змістової складової частини, незалежно від форми документа, в якому він міститься) і як такий може бути предметом судового контролю в порядку адміністративного судочинства у разі звернення із відповідним позовом. «Законність» письмової вимоги контролюючого органу передбачає іiї обгрунтованість, тобто наявність підстав для ії скерування адресату [13];

5) рішення про реєстрацію (наприклад, податкової накладної / розрахунку коригування в Єдиному реєстрі податкових накладних та / або відмову в такій реєстрації та рішення про включення в ризикові);

6) накази щодо питань проходження публічної служби (як приклад, Головного управління Національної поліції); 
7) інші індивідуалізовані, конкретизовані рішення органів виконавчої влади, наприклад, постанови Департаменту Державної архітектурно-будівельної інспекції, постанови Національної комісії, що здійснює державне регулювання у сферах енергетики та комунальних послуг.

Усі перелічені акти після реалізації вичерпують свою дію, не встановлюють і не змінюють норми права, мають локальний характер, не розраховані на широке коло осіб [4].

Говорячи про акти, які не належать до індивідуальних, необхідно вказати, що це листи, інформаційні буклети, попередження (нагадування), рекомендації тощо.

Водночас слід розуміти, що не всі акти можна оскаржити. Зокрема, підставою для відмови в оскарженні $є$ припинення дії такого акта (його виконання), а також відсутність порушення безпосередньо прав, свобод чи охоронюваних законом інтересів позивача (і не належний позивач, i не відсутність порушення як такого).

Слід також зазначити, що право на оскарження $є$ динамічним, багатоаспектним і продовжує змістовно розвиватися разом із розширенням нашого уявлення про права людини, верховенство права та про його складові елементи [3, с. 78].

Висновки. Усе вищевикладене дає можливість сформулювати висновок, згідно з яким інститут оскарження індивідуальних актів суб'єктів владних повноважень вважається одним із фундаментальних у системі адміністративного судочинства. Суб'єкти, наділені владними функціями, не завжди дотримуються встановлених правил прийняття (створення) актів застосування, що нерідко призводить до порушення прав об'єктів управління (якими ті є).

Узагальнено такі акти прийнято поділяти за суб'єктом видання на рішення органів виконавчої влади, органів місцевого самоврядування, делегованих представників, наділених виконавчими функціями у сфері управління. Однак фактично це об'єктивовані у певному виражені наслідки використання такими суб'єктами своїх компетенційних можливостей як результат використання ними однієї із форм адміністративної діяльності, репрезентованої у вигляді наказу, розпорядження, постанови тощо.

\section{Список використаних джерел:}

1. Корчинський О.І. Правові засади організації адміністративного судочинства в Україні : дис. ... канд. юрид. наук : 12.00 .07 ; Міністерство освіти і науки України, Національний університет «Львівська політехніка». Львів, 2019. 185 с.

2. Кодекс адміністративного судочинства України : Закон України від 06 липня 2005 p. № 2747-IV. Урядовий кур’єр. 2005. № 153. С. 153-154.

3. Цельєв О.В. Право на оскарження рішень органів публічної влади та їхніх посадових осіб як складова верховенства права. Наукові записки НаУКМА. Серія : Юридичні науки. 2017. T. 200. C. 72-29.

4. Справа № 520/5501/19. Сдиний держсавний реєстр судових рімень Украйни. 2019. URL: http://reyestr.court.gov.ua/Review/83598057.

5. Справа№200/11391/19-а. Сдиний державний реєстр судових рімень Украйни. 2019. URL: http://reyestr.court.gov.ua/Review/86493721.

6. Справа № 560/1809/19. Єдиний державний реєстр судових рімень Украӥни. 2019. URL: http://reyestr.court.gov.ua/Review/83904880.

7. Справа № 240/7848/19. Сдиний державний реєстр судових рімень Украӥни. 2019. URL: http://reyestr.court.gov.ua/Review/83292391.

8. Пунько О.В. Функції правозастосовних актів. Науковий вісник Ужгородського національного університету. Серія Право. 2015. Вип. 31. Т. 1. С. 34-36.

9. Бевзенко В. Рішення, дії та бездіяльність суб'єктів владних повноважень - що оскаржується до адміністративного суду. “Судебно-юридическая газета». 2020. URL: https://supreme. court.gov.ua/supreme/pres-centr/zmi/917730/.

10. Адміністративна юстиція України: проблеми теорії та практики. Настільна книга судді / за заг. ред. О.М. Пасенюка. Київ : Істинна, 2007. 608 с.

11. Про практику застосування адміністративними судами окремих положень Кодексу адміністративного судочинства України під час розгляду адміністративних справ : Постанова Вищого адміністративного суду від 06 березня 2008 р. № 2. Вісник Вищого адміністративного суду України. 2008 р. № 2. С 117.

12. Справа № 2а-1672-1/09. Сдиний державний реєстр судових рімень Украӥни. 2019. URL: http://reyestr.court.gov.ua/Review/12665643.

13. Окрема думка по справі № 520/9092/18. Єдиний державний реєстр судових рішень України. 2019. URL: http://reyestr.court.gov.ua/Review/ 81794516. 